University of Nebraska - Lincoln

DigitalCommons@University of Nebraska - Lincoln

1970

\title{
A Summary of Intergeneric New World Quail Hybrids, and a New Intergeneric Hybrid Combination
}

Paul A. Johnsgard

University of Nebraska-Lincoln, pajohnsgard@gmail.com

Follow this and additional works at: https://digitalcommons.unl.edu/biosciornithology

Part of the Ornithology Commons

Johnsgard, Paul A., "A Summary of Intergeneric New World Quail Hybrids, and a New Intergeneric Hybrid Combination" (1970). Papers in Ornithology. 77.

https://digitalcommons.unl.edu/biosciornithology/77

This Article is brought to you for free and open access by the Papers in the Biological Sciences at DigitalCommons@University of Nebraska - Lincoln. It has been accepted for inclusion in Papers in Ornithology by an authorized administrator of DigitalCommons@University of Nebraska - Lincoln. 


\section{A SUMMARY OF INTERGENERIC NEW WORLD QUAIL HYBRIDS, AND A NEW INTERGENERIC HYBRID COMBINATION}

\section{PAUL A. JOHNSGARD}

Department of Zoology

University of Nebraska

Lincoln, Nebraska 68505

The exceedingly close affinities of the quail genera Colinus, Callipepla, and Lophortyx have been recognized for some time and have recently been emphasized by additional morphological (Holman 1961; Hudson et al. 1966), biochemical (Sibley 1960), and pterylographic (Ohmart 1967) evidence. Indeed, Holman has suggested that these three taxa might best be regarded as subgenera. Phillips et al. (1964) pragmatically merged Lophortyx with Callipepla; and Delacour (1961-1962) synonymized not only Lophortyx, but also Oreortyx and Philortyx, with Callipepla, yet retained Colinus as a separate genus. Although Ohmart (1967) questioned the validity of generically separating Lophortyx and Callipepla, he suggested that any new taxonomic reorganization should also include consideration of such related genera as Colinus.

One useful source of evidence for judging possible generic distinction is the occurrence of both naturally occurring and artificially obtained hybrids, and their relative fertility. Thus, before advocating any taxonomic changes among the New World quail genera, a review of recorded intergeneric hybrids would seem to be in order.

\section{CALLIPEPLA $\times$ COLINUS}

Natural sympatry between the Bobwhite ( $\mathrm{Co}$ linus virginianus) and the Scaled Quail (Callipepla squamata) exists across a fairly broad zone extending from northern Mexico through west-central Texas (McCabe 1954), the Oklahoma panhandle (Schemnitz 1964; Sutton 1967), possibly extreme southwestern Kansas (Johnston 1964), and southeastern Colorado (Hoffman 1965; Bailey and Niedrach 1965). Wild hybrids have been reported in Texas from Concho County (McCabe 1954), Stonewall County (Sutton 1963), and Motley County (Schemnitz 1964). Probable hybrids have also been seen in Oklahoma (Sutton 1967). Captive hybrids have also been produced on a variety of occasions (Gray 1958). Although the hybrid females are known to produce eggs, attempted inter se matings and back-cross matings with Bobwhites have not yet proven successful (Sutton 1963).

\section{CALLIPEPLA $\times$ LOPHORTYX}

The range of the Scaled Quail overlaps fairly extensively with that of the Gambel Quail ( $L$. gambelii), primarily in New Mexico (Campbell and Lee 1953; Ligon 1961), but also in western Texas along the Rio Grande (Texas Game, Fish, and Oyster Commission 1949), southeastern Arizona (Phillips et al. 1964), and adjacent México (Leopold 1959). Introductions of the Scaled Quail into central Washington have also resulted in a small amount of contact with the California Quail (L. californicus), and two hybrid specimens have been reported from that area (Jewett et al. 1953). Shore-baily (1912, 1913, 1914, 1917) bred and reared a number of such hybrids, and reported them to be fertile. There is apparently no natural contact between the Scaled Quail and the Douglas Quail (L. douglasii) in northern México, but several examples (all apparently sterile) of such a hybrid combination have been obtained in captivity (Banks and Walker 1964).

Wild hybrids between the Scaled Quail and Gambel Quail have been known to occur for some time; apparently the earliest published record is that of Bailey (1928), who described a male hybrid shot from a covey of Gambel Quail during 1916 in Grant County, New Mexico. Hachisuka (1928) also illustrated this specimen. More recently Hubbard (1966) described an apparent back-cross to Gambel Quail, taken in Grant County in 1930. Phillips et al. (1964) reported three hybrid specimens from different localities in southeastern Arizona and Lowe (1964) mentioned wild hybrids from one of the same areas. Captive hybrids have been reported by Plath (1953) and have also been obtained by the author (male Scaled $\times$ female Gambel). According to J. S. Ligon, such female hybrids lay only sterile eggs (Sibley 1961), but eggs that developed nearly to hatching (when the incubator failed) have been produced by a hybrid pair at the Arizona-Sonora Desert Museum (L. W. Walker, pers. comm.).

\section{LOPHORTYX $\times$ OREORTYX}

The area of geographic overlap between the Mountain Quail (O. picta) and the California Quail is considerable and includes much of 
California, Oregon, and western Washington (Grinnell and Miller 1944; Jewett et al. 1953; Masson and Mace 1962). The earliest record of a hybrid between these species is that of Peck (1911), who described a specimen taken in 1911 in Harney County, Oregon. Hachisuka (1928) provided an illustration of this hybrid specimen. Peterle (1951) published a reproduction of a painting by L. A. Fuertes of a presumably wild hybrid in the collection of L. M. Loomis, the skin of which is no longer extant.

There do not appear to be any hybrids between Oreortyx and Lophortyx produced in captivity, nor are there any naturally occurring or captive-bred hybrids known that involve the Mountain Quail and Callipepla or Colinus. With the possible exception of the introduced Bobwhite in northern Oregon (Masson and Mace 1962), the current range of the Mountain Quail would preclude any natural hybridization with these species. Interestingly, Holman (1961) suggests that Oreortyx may actually be more closely related to Callipepla than to Lophortyx, which points out the fallacy of distinguishing genera primarily on the basis of crest condition.

\section{LOPHORTYX $\times$ COLINUS}

Natural sympatry between these two genera is essentially non-existent, although there may be some overlapping of marginal ranges of the Bobwhite and the Gambel Quail in extreme western Texas near El Paso (Peterson 1960). Additionally, there is some potential contact between the nearly extinct Masked Bobwhite (C. v. ridguayi) and the Gambel Quail or Douglas Quail in western México (Leopold 1959). Furthermore, introduction of the Bobwhite into Washington, Oregon, and Idaho has resulted in some probable contact with the California Quail. Finally, introduction of the Bobwhite and the California Quail into Utah also produced a relatively short-lived sympatry between them and resulted in the only known naturally occurring intergeneric hybridization between Colinus and Lophortyx. Aiken (1930) described three probable Bobwhite $\times$ California Quail hybrids taken in 1895 near Salt Lake City. Compton (1932) likewise described a male hybrid that apparently resulted from keeping a female Bobwhite in a pen with California Quail.

As part of a general study on the behavior and relationships of odontophorine quail, I have attempted to produce various intergeneric hybrids involving Colinus, Lophortyx, and Callipepla. In October 1967 a mixed pair involving an immature male Bobwhite and female

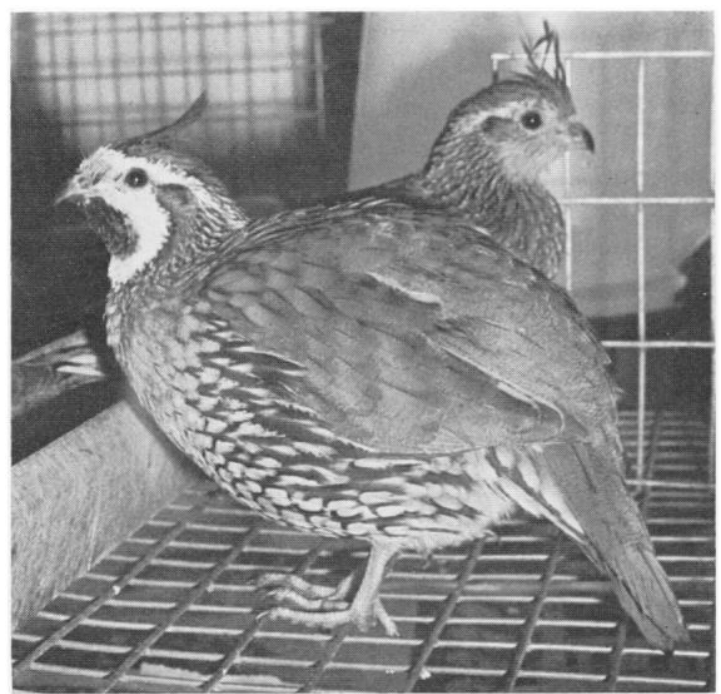

FIGURE 1. Pair of $F_{1}$ Bobwhite $\times$ Gambel Quail hybrids, at 140 days of age.

Gambel Quail was established. The birds were not allowed visual contact with others of their species, but auditory communication was possible. They were placed on a $17-\mathrm{hr}$ photoperiod and were minimally disturbed, although this pair was kept only a few feet from my office desk. The female began to produce eggs in early February, and while several were used for other purposes, a total of 17 eggs were artificially incubated. All of them proved to be fertile, but of the first group of five eggs only a single individual hatched, the other four having died just prior to pipping. This individual also died two days later, perhaps as a result of faulty incubation procedures. The 12 remaining eggs all hatched between 30 March and 16 April and resulted in apparently healthy and normal chicks. Various accidents and cannibalism gradually reduced this number, but two individuals were ultimately reared to their first winter plumage (figure 1).

\section{TAXONOMIC IMPLICATIONS}

The primary criteria for the genera Lophortyx, Callipepla, and Colinus have been variations in the number of rectrices ( 14 in Callipepla, 12 in the others), the degree of sexual dimorphism, and the condition of the crest (Ridgway and Friedmann 1946). The first of these criteria is weakened by the fact that some individuals of at least two species of Lophortyx may have as many as 14 rectrices (Clark 1898; Ohmart 1967). The degree of sexual dimorphism is of little or no significance at the generic level, since it is the result of various factors such as the intensity of sexual selection and the relative requirements for species and sexual recog- 


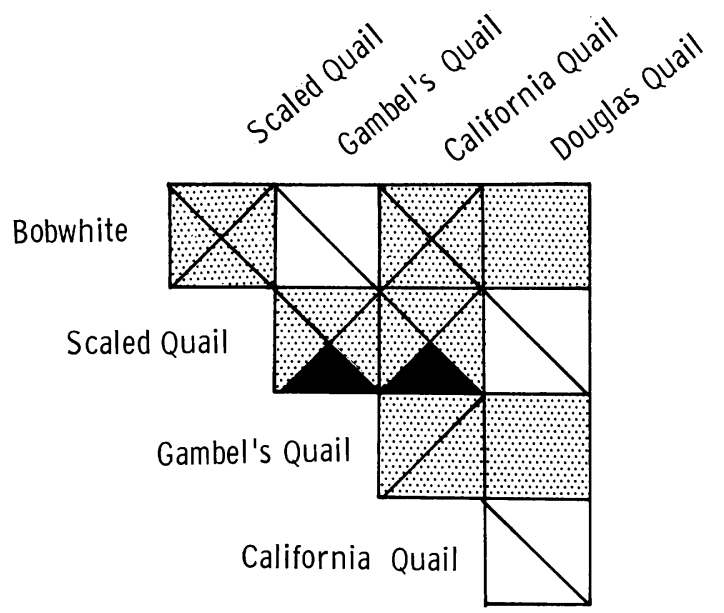

7

Presumed Wild Hybrids Reported

Hybrids Reported From Captivity

Wild and Captive Hybrids; Infertile or Fertility Not Established

Hybrids Reported to be at least Occasionally Fertile

Apparently Sympatric at Present

or in the Recent Past

FIGURE 2. Summary of interspecific hybrid records among species of Colinus, Callipepla, and Lophortyx. Sympatric contact has also been indicated, even in situations of slight geographic overlap or possible ecological barriers to extensive contact.

nition signals (Sibley 1957). Finally, although crest shape and length among the species of Lophortyx and Callipepla varies considerably, the pterylographic arrangements of these feathers are almost identical (Ohmart 1967). Differences in the relative proportions of tail-to-wing lengths and the variations in scapular and tertial spotting are likewise unconvincing generic criteria.

Collectively considering the three species of Lophortyx, the one species of Callipepla, and the single North American species of Colinus, there are 10 intra- and intergeneric hybrid combinations possible. At least eight of these have been actually achieved, including five from presumably wild birds and seven from captivity, while four combinations have occurred both in captivity and under natural conditions (figure 2). Remarkably, four of the five recorded combinations that have occurred naturally are intergeneric on the basic of current nomenclature. So far, the only possible combinations that remain unrecorded are crosses of the Douglas Quail with the Bobwhite and Gambel Quail, although Ridgway and Friedmann (1946) believe that "Lophortyx leucoprosopon" may have been described on the basis of two captive-bred birds representing the latter hybrid combination. At least one intergeneric cross (Scaled $\times$ California Quail) has been reported to be fully fertile, and one other Callipepla $\times$ Lophortyx combination is apparently occasionally fertile. The fertility of the Colinus $\times$ Lophortyx cross is as yet unknown.

Continued comparative studies on all these species and their hybrids are planned, and ultimately specific taxonomic recommendations are contemplated. At present, however, it is clearly apparent that serious consideration should be given to merging the genera Lophortyx and Callipepla with Colinus, and that the question of the validity of Oreortyx and Philorty $x$ should be kept open for further assessment.

\section{SUMMARY}

A review of hybridization records among the New World quail indicates that the five North American species of Colinus, Callipepla, and Lophortyx have been hybridized in at least eight of the ten possible combinations. On the basis of inadequately distinctive morphological criteria, the several known cases of naturally occurring intergeneric hybridization, and the intergeneric fertility of at least one such hybrid combination, it is suggested that Lophortyx and Callipepla be merged with Colinus.

\section{ACKNOWLEDGMENTS}

This study was financed in part by a National Science Foundation research grant (GB-7666X), and in part by University of Nebraska Zoology Department funds; it is Study No. 394 from the Department of Zoology. I express my appreciation to both of these organizations.

\section{LITERATURE CITED}

Arken, C. E. H. 1930. A Bobwhite $\times$ California Quail hybrid. Auk 47:80-81.

BAILEY, V. 1928. A hybrid Scaled $\times$ Gambel's Quail from New Mexico. Auk 45:210.

Bailey, A. M., and R. J. Niedrach. 1965. Birds of Colorado. Vol. 1. Denver Museum of Natural History, Denver.

Banks, R. C., ANd L. W. Walker. 1964. A hybrid Scaled $\times$ Douglas Quail. Wilson Bull. 76:378380.

Campbell, H., and L. Lee. 1953. Studies on quail malaria in New Mexico, and notes on other aspects of quail populations. New Mexico Dept. of Fish and Game, Project W-41-R.

Clark, H. L. 1898. The feather-tracts of North American grouse and quail. Proc. U.S. Natl. Mus. 21:641-653.

Compton, L. V. 1932. A probable hybrid between the California Quail and the Texas Bob-white. Condor 34:48. 
Delacour, J. 1961-1962. The American quails (Tribe Odontophorini). Avicult. Mag. 67:12-18; 68:15-19.

Gray, A. P. 1958. Bird hybrids. Commonwealth Agri. Bur., Royal Banks, England.

Grinnell, J., AND A. H. Miller. 1944. The distribution of the birds of California. Pacific Coast Avifauna, no. 27.

HaCHISUKA, M. 1928. Varieties among birds (chiefly game birds). Suppl. Publ. Ornithol. Soc. Japan, no. 12.

Hoffman, D. M. 1965. The Scaled Quail in Colorado. Tech. Publ. no. 18, Colorado Dept. of Game, Fish and Parks.

Holman, J. A. 1961. Osteology of living and fossil New World quails (Aves, Galliformes). Bull. Florida State Mus., Biol. Sci. 6(2):131-233.

Hubbard, J. P. 1966. A possible back-cross hybrid involving Scaled and Gambel's Quail. Auk 83: 136-137.

Hudson, G. E., R. A. Parker, J. V. Berge, and P. J. LANziLOTTI. 1966. A numerical analysis of the modifications of the appendicular muscles in various genera of gallinaceous birds. Amer. Midland Naturalist 76:1-73.

Jewett, S. C., W. P. Taylor, W. T. Shaw, and J. W. AldRICH. 1953. Birds of Washington State. Univ. Washington Press, Seattle.

Johnston, R. F. 1964. The breeding birds of Kansas. Univ. Kansas Publ., Mus. Nat. Hist. 12(14): $575-655$.

Leopold, A. S. 1959. Wildlife of Mexico. The game birds and mammals. Univ. California Press, Berkeley.

Ligon, J. S. 1961. New Mexico birds and where to find them. Univ. New Mexico Press, Albuquerque.

LowE, C. H. 1964. The vertebrates of Arizona. Univ. Arizona Press, Tucson.

McCabe, R. A. 1954. Hybridization between the Bob-white and Scaled Quail. Auk 71:293-297.

Masson, W. V., and R. U. Mace. 1962. Upland game birds. Bull. no. 5, Oregon State Game Comm., Portland.

Ohmart, R. D. 1967. Comparative molt and pterylography in the quail genera Callipepla and Lophortyx. Condor 69:535-548.
Peck, M. E. 1911. A hybrid quail. Condor 13: 149-151.

Peterle, T. J. 1951. Intergeneric galliform hybrids: a review. Wilson Bull. 63:219-224.

Peterson, R. T. 1960. A field guide to the birds of Texas. Houghton Mifflin, Boston.

Phillips, A. R., J. T. Marshall, and G. Monson. 1964. The birds of Arizona. Univ. Arizona Press, Tucson.

Plath, K. 1953. A diary for 1952 of new arrivals in the Bird Department of the Brookfield Zoo at Brookfield, Ill. Avicult. Mag. 59:104-107.

Ridgway, R., And H. Friedmann. 1946. The birds of North America. U.S. Natl. Mus., Bull. 50. Pt. 10.

SCHEMnitZ, S. D. 1964. Comparative ecology of Bobwhite and Scaled Quail in the Oklahoma panhandle. Amer. Midland Naturalist 71:429-433.

Shore-baily, W. 1912. Quail hybrids. Bird Notes $3: 322$.

Shore-baily, W. 1913. Fertility of hybrid quail. Bird Notes $4: 326$.

Shore-baILY, W. 1914. Hybrid quail. Bird Notes $5: 31-32$.

Shore-baILy, W. 1917. Hybrid breeding. Bird Notes $8: 13-16$

Sibley, C. G. 1957. The evolutionary and taxonomic significance of sexual dimorphism and hybridization in birds. Condor 59:166-191.

Sibley, C. G. 1960. The electrophoretic patterns of avian egg-white proteins as taxonomic characters. Ibis $102: 215-284$.

Sibley, C. G. 1961. Hybridization and isolating mechanisms. p. 69-88. In W. Frank Blair [ed.] Vertebrate speciation. Univ. Texas Press, Austin.

Sutton, G. M. 1963. Interbreeding in the wild of the Bobwhite (Colinus virginianus) and Scaled Quail (Callipepla squamata) in Stonewall County, northwestern Texas. Southwestern Naturalist 8: 108-111.

Sutton, G. M. 1967. Oklahoma birds. University of Oklahoma Press, Norman

Texas Game, Fish, and Oyster Commission. 1949. Principal game birds and mammals of Texas.

Accepted for publication 19 September 1968. 